\title{
PHD THESIS SUMMARY: \\ Keynes, Keynesian economics and the political economy of power of the postwar world
}

\author{
DANIELle C. GUIZZO ARCHELA \\ PhD in public policy, June 2016 \\ Federal University of Parana
}

The economic origins and sociopolitical impacts of what became known as 'Keynesian Economics' have not received substantial attention from economists, political scientists, and philosophers about its mode of governance. This thesis explores the rise and consolidation of Keynesianism as a mode of governance responsible for creating collective forms of power relations in the postwar world, investigating the possible effects of economic ideas once they reach the political arena. Specifically, we apply a "political economy of power" (PEP) framework to understand the emergence of Keynes's economic theory and its transformation into a policy agenda that had specific consequences in terms of power, governance, and regulation of the economy and the population. Whilst chapters 1 and 2 respectively promote a bibliographical reading of Michel Foucault's genealogy of power and John Maynard Keynes's economic, philosophical, and political foundations, chapter 3 introduces a historical investigation based on primary sources and official documents about the absorption and acceptance of the Keynesian economic theory in postwar's economic policies. Our PEP framework developed throughout chapter 4 deploys a dual-historical approach, combining institutional and genealogical aspects to analyze the transformation of Keynesianism into a policy agenda between the end of the 1930s and beginning of 1970s across Western Europe and the United States. Our conclusions are buttressed by the epistemological and political shift caused by Keynesianism as a political paradigm, or a "governmentality". The Keynesian mode of governance was successful in bringing economistic principles and economic technicality into life, thus affecting the ways populations are governed. Consequently, technical economic instruments and welfare systems were actually a technical-scientific justification of intervention via a discourse of power that defended stability, economic growth, and welfare. Once Keynesianism established itself as a mode of 
governance we see the rise of a security society where the "social" consolidates itself as a political subject. Policies involving full employment, demand management, economic stability, and social security point out towards new forms of economic control and regulation in the shape of a security pact between the state and the population. In that context, we invite the reader to return to the aforementioned intellectuals and reflect on the effects and forms of resistance to such economic powers. For Keynes, economics actually represented a means towards bigger ethical objectives in the sense of a construction of the self, which is quite similar to Foucault's assertions on the government of the self. If economics consolidated itself as a theory of production and allocation that seeks the improvement of life, what are prosperity and economic outcomes for? Economic technicality, stability, and security policies should represent the means instead of the ends of economics. By exploring the ethical writings of Keynes and Foucault from a complementary perspective, we stress how economics should be reviewed and reconsidered as a means to achieve an ethical end: the good life. Such trajectory, in Foucault's rationale, becomes a form of self-government in which the individual transforms himself/herself within the economy and understands economic activity as a means of action-rather than an end.

Danielle C. Guizzo Archela is a lecturer in economics at the Bristol Business School, University of the West of England (Bristol, UK). She obtained a $\mathrm{PhD}$ in public policy (with an emphasis in political economy) from the Federal University of Parana (Brazil) in June 2016, under the supervision of Iara Vigo de Lima. During her $\mathrm{PhD}$ she was a visiting research fellow at the University of the West of England, funded by the CAPES Research Foundation. Danielle is a member of the YSI INET Group on the history of economic thought, and has a MSc in public policy and a BSc in economics from the Federal University of Parana (Brazil). Her articles have appeared in journals such as Review of Political Economy, Review of Radical Political Economics, and EconomiA (ANPEC).

Contact e-mails: <danielle.guizzoarchela@uwe.ac.uk> and $<$ danielleguizzo@gmail.com> 